\title{
Giorgio Vasari’s Saint Michael: A Symbol of Neoplatonic Light
}

\author{
Liana De Girolami Cheney \\ University of Coruña, Coruña, Spain
}

\begin{abstract}
"O fortunately-born one, you, to whom grace concedes the right to see the thrones of eternal triumph, before you abandon the place of militancy, we are fired by the light that burns through all the heavens, and therefore if you want to be lit by us, satisfy yourself at pleasure.” Dante, The Divine Comedy, Paradise, Canto V
\end{abstract}

\begin{abstract}
This essay includes a brief explanation of who is Michael The Archangel; discusses the manifold depictions of Saint Michael in Italian Renaissance art, in particular in Giorgio Vasari’s imagery; and examines the impact of Neoplatonism in the interpretation of The Archangel and Michael's symbolic role. The Renaissance Neoplatonic philosopher Marsilio Ficino explained the signification of the Platonic celestial ladder as a spiritual vehicle for the human soul to achieve the divine's love. One step of this ladder is the Angelic Mind. The sparkling light of the Angelic Mind's realm reveals the splendor and beauty of God's grace. This is the realm where Michael, a Seraphim and a messenger of God, resides, delivering God's messages of grace and love to humanity throughout the world. In the vault of the Pope Pius V Chapel at the Vatican, once called Saint Michael's Chapel, for example, Giorgio Vasari (1511-1574) metaphorically visualized these divine messages. He painted al fresco Michael The Archangel in combat against personifications of vices as demons who want to prevent human beings from the obtaining divine grace that will allow their souls to ascend toward divine love.
\end{abstract}

Keywords: Saint Michael, Giorgio Vasari, Neoplatonism, Light, and Symbolism

\section{Introduction}

This essay consists of three parts: 1) a brief explanation of who is Michael The Archangel; 2) the multiple visual roles of Michael, as a saint in art, focusing on Italian Renaissance art, in particular on Giorgio Vasari's imagery; and 3) a Neoplatonic interpretation of the symbolic role of Michael.

\section{Section I: Who Is Michael The Archangel?}

The name Michael signifies “Quis ut Deus? Quis resistet Sancti Michaelis gladio?” (Who is like unto God? Who can withstand the sword of Saint Michael?). This is a rhetorical question alluding to Michael's humility in front of God, because no one is actually like God (Daniel 10:33). ${ }^{1}$

\footnotetext{
Liana De Girolami Cheney, Ph.D., professor, Research Scholar in Art History at the University of Coruña.

Correspondence concerning this article should be addressed to Liana De Girolami Cheney. E-mail: lianacheney@earthlink.net. 1 See Richard Webster, Michael (Woodbury, MN: Llewellyn Worldwide, 2010), 1-23; Julian of Norwich, ed., The Book of Revelations of Divine Love (Baltimore, MD: Penguin Books, 1999); Revelation 12:7-9, on Saint Michael; Martin Goodman, et al., The Apocrypha (New York/London: Oxford University Press, 2012), Chapter 8, on the dragon; and Estelle M. Hurll, ed., Sacred and Legendary Art by Anna Jameson (Boston: Houghton Mifflin and Company, 1895), 89-111, on Saint Michael's origin of worship and description of his imagery.
} 
Through the centuries, Michael has been honored in Judaism and Christianity, including the Greek Orthodox and Protestant faiths. In the Bible, Michael is considered "one of the chief heavenly princes", who lead the forces of heaven to triumph over the powers of hell. In the Old Testament (Genesis 3:23, Numbers 22:22-24; and IV Kings 19:35), God assigned four duties to Michael: 1) defender, to fight against the evil forces of Lucifer, Satan; 2) healer, to rescue from their enemies the souls of the faithful at their hour of death; 3) protector, to champion God; and 4) intercessor.

The biblical references to Michael are mostly derived from the Book of Daniel, where he is described as a guardian angel of the Hebrew nation, to call and judge human souls on the Day of Judgment (Daniel 12), as well as in the Apocalypse (12:7), which relates how Michael as an angel stood at the gate of heaven to keep the way free of evil.

In the Old Testament, Michael is perceived as the protector of the people of Israel and, in particular, of Abraham and Moses. For example, Michael rescued Abraham from inside the furnace placed by vicious Nimrod, King of Persia ("He who made all the people rebellious against God"; Midrash Genesis Rabbal xliv.16 and Pes.94b), and he saved Lot from the destruction of Sodom. Michael also announced to Sarah that she would bear a son, Isaac. Michael's presence on earth—that is, his descent from heaven-is also noted in the Quran (Sura 11:69), which describes his visit, along with two other angels, to Abraham.

Michael's interactions with Moses are instrumental for the Judeo-Christian faithful. In the Book of Revelation (20:1), for example, Moses went to Mount Sinai to hear the word of God, a burning bush appeared to him, and angelic voice from the flames delivered God's law to him. This fire and voice are aspects of Michael, who, as a messenger of God, descended from heaven to earth in the form of a burning bush to convey to Moses the wishes of God. ${ }^{2}$ Michael here revealed his mercurial power as an angelic Seraphim. The connection between Moses and Michael is further explained in the Epistle of Jude (1:9) and in Origen's De Principiis (III2, 2, Revelations of Moses), when Michael engaged in combat with Lucifer for the body of Moses. According to the Scriptures, Lucifer wished to possess the dead body in order to impersonate Moses and deceive the Jewish people; hence Michael concealed the tomb of Moses from the Saki. ${ }^{3}$

In the New Testament, Michael not only is referred to as an archangel (Epistle of Jude 1:9 and Revelation 12:22), but also is considered to be defender of the Christian faith because of his valiant struggle with the devil. For example, in the First Epistle to the Thessalonians, Paul said, "The Lord himself will descend from heaven with a cry of command, with the voice of an archangel, and with the sound of the trumpet of God" (I Thessalonians 4:16). According to the New Testament, Michael also appeared on earth to carry the souls of the deceased to heaven. ${ }^{4}$

In the teachings of Christianity, Michael also embodied triumph, because he was successful in overcoming the forces of evil. Similar to Christ, who triumphs over the anti-Christ, Michael's conception of spiritual and natural triumph was over the evil forces of the spirit and nature, as noted in the Book of Revelation (12:7-9): "Then war broke out in heaven. Michael and his angels fought against the dragon [evil]. And the great dragon was cast out, that old serpent, called the Devil, and Satan, which deceived the whole world.” The combat

\footnotetext{
${ }^{2}$ See Louis Ginzberg, The Legend of the Jews, 2 vols. (Philadelphia: The Jewish Publication Society of America, 1909, repr. Charleston, SC: Nabu Press, 2010), vol. 2, 303; and Hurll, Sacred and Legendary Art, 109.

${ }^{3}$ See Hurll, Sacred and Legendary Art, 109; and Alexander Walker, ed., Revelations of Moses, The Apocryphal Gospels (Edinburg: np, 1873), 647. See <http://www.newadvent.org/cathen/10275b.htm>.

${ }^{4}$ See Mirabai Starr, Saint Michael: The Archangel (Louisville, CO: Sounds True, 2007), 39.
} 
between the good and bad angels is related to the fallen angels, causing the fall of the most beautiful but most proud angel, Lucifer, light-bearer (in Greek heosphoros). ${ }^{5}$ The Bible says: "Satan falls like lightning from the heaven" (Isaiah 14:1-17, Revelation 2:8-9, Luke 10:18).

Worship of Michael is rooted in the ancient Persian religion, which explained the war between two faiths, between good and evil, or between gods of light and the gods of darkness. ${ }^{6}$ Michael as a seraph represents light that triumphs over darkness. He is identified as the Prince of Light, as depicted in Giorgio Vasari's Saint Michael and the Devils of 1560-1566, in the vault of the Chapel of Pope Pius V, at the Vatican (originally called Saint Michael's Chapel, Figures. 1A-B).

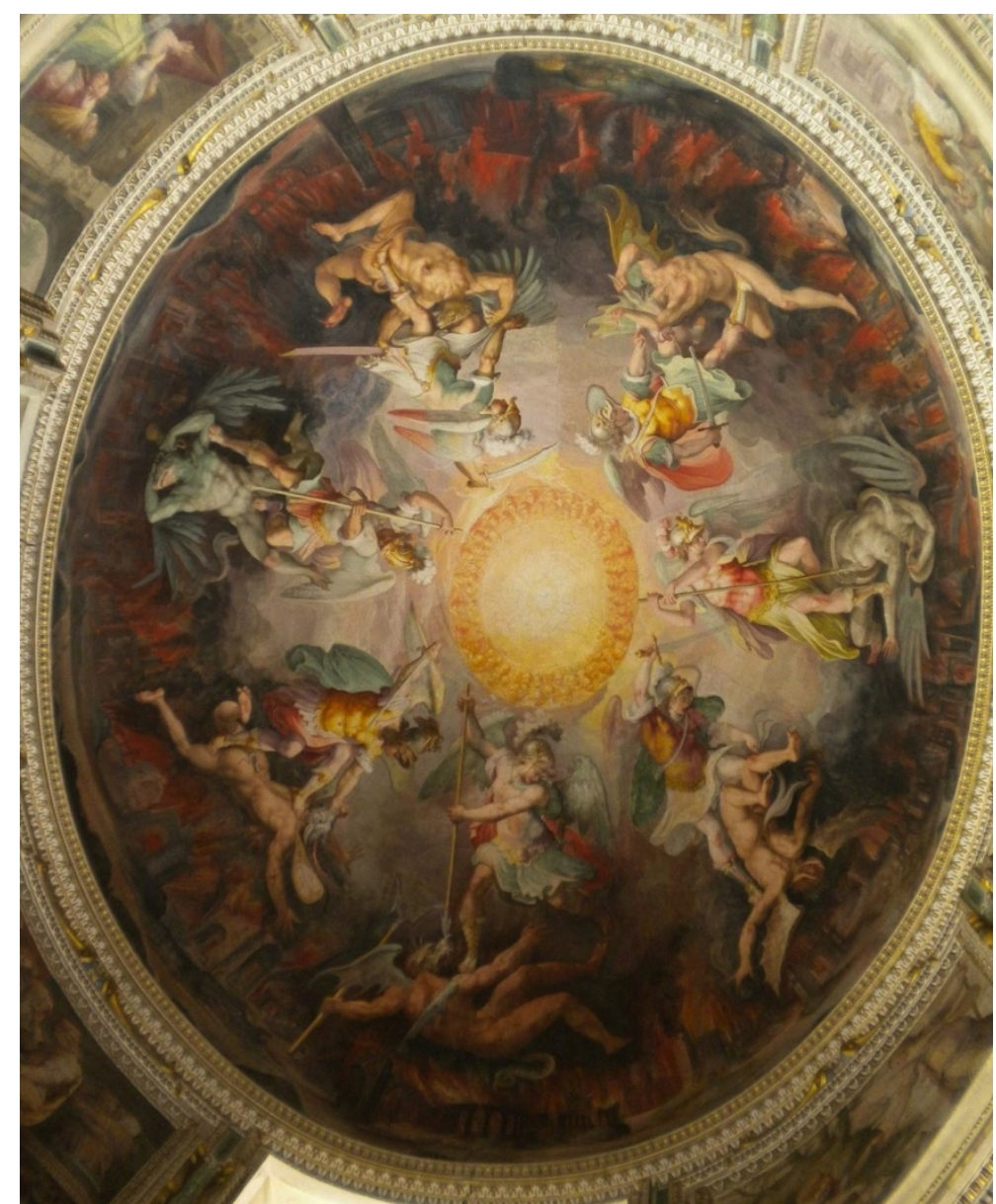

Figure 1. A. Giorgio Vasari’s Saint Michael and the Devils, 1560-66. Vault of the Chapel of Pope Pius V, Vatican. Photo credit: author, courtesy of the Vatican.

\footnotetext{
${ }^{5}$ See Maude Vanhaelen, "Marsilio Ficino and the Irrational," in Machtelt Israëls and Louis A. Waldman, eds., Renaissance Studies in Honor of Joseph Connors, 2 vols. (Cambridge, MA: Harvard University Press, 2013), vol. 2, 440-443, for a discussion on the paradox of the fallen angels.

<http://www2.warwick.ac.uk/fac/arts/classics/staff/vanhaelen/publications/2-59_vanhaelen.pdf>.

${ }^{6}$ See Hurll, ed., Sacred and Legendary Art, 89.
} 


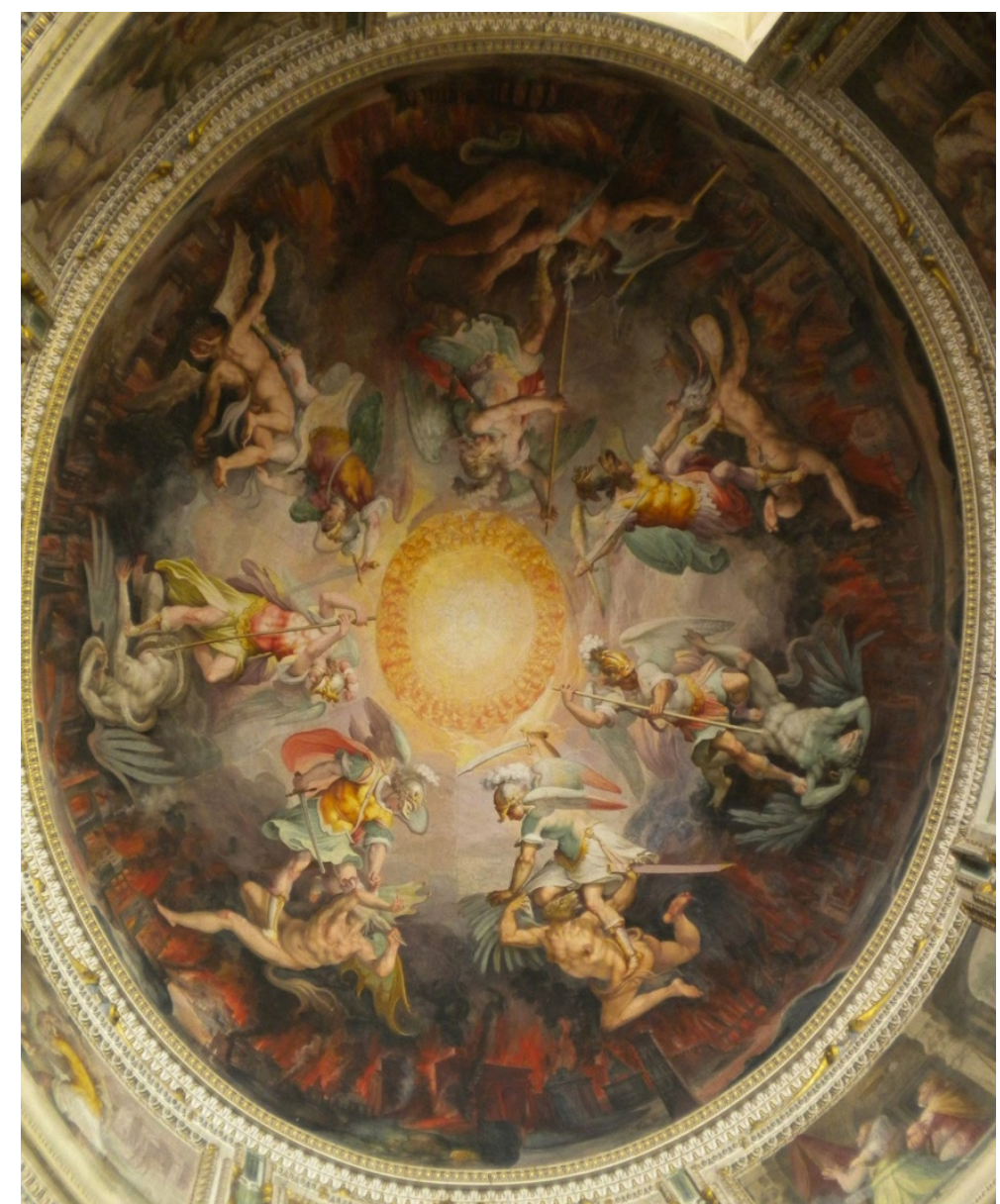

Figure 1. B. Giorgio Vasari's Saint Michael and the Devils, 1560-66. Vault of the Chapel of Pope Pius V, Vatican. Photo credit: author, courtesy of the Vatican.

The earliest reference to Michael as a holy person occurs in the early fourth century in the Near East at Chalcedon, when Emperor Constantine built a temple in his honor, Michaelion. ${ }^{7}$ This site, known for its healing waters, was created as a result of Michael's curative powers. In the West, in the fourth century, Saint Basil the Great's homily De Angelis honors Michael above all the angels because of his healing powers against the plague and illness. In Rome, in the sixth century, churches were built in Michael's honor, such as the church of Castel Sant’ Angelo and the Basilica Archangeli (originally in via Salaria). ${ }^{8}$

Since antiquity, heavenly figures were associated with men in white robes or figures with wings. The winged figures symbolized victory and were called nike figures, a prototype for messengers or angeloi-a Greek word for angel—such as Michael The Archangel. Traditionally, the role of the angels is manifold: Mostly they are mediators between God and individuals, connecting the metaphysical (spiritual) and physical (natural) realms, the invisible and visible worlds, the heavenly and earthly spheres, and the temporal and spatial domains. The formation of angelology is constructed differently in various religious traditions such as Christianity, Judaism, and Islam, but it always rests on a hierarchical foundation. (A comparative analysis of

\footnotetext{
7 See Cyril Mango, “St. Michael and Attis,” Deltion tes Christianikes Archaiologikes Hetaireas, ser 4, vol. 12 (1986), 39-62, for a study on the origin of the worship of St. Michael and iconography.

${ }^{8}$ See F. L. Cross, ed., The Oxford Dictionary of the Christian Church (Oxford/New York: Oxford University Press, 1984$), 913$.
} 
these hierarchies is beyond the scope of this study).

The most elaborate study in angelology occurred in the fifth century, with the Christian theologian and philosopher Pseudo-Dionysius the Areopagite, in his De coelesti hierarchia (On the Celestial Hierarchy). ${ }^{9}$ He composed an angelic hierarchical construction of three spheres and nine circles of angels. The first sphere is composed of Seraphim, Cherubim, and Thrones; the second one of Dominions, Virtues, and Powers (Authorities); and the third one of Principalities (Rulers), Archangels, and Angels. During the Middle Ages, this Christian classification, with few modifications, was incorporated in Thomas Aquinas' (1225-1274) Summa Theologiae (Figure. 2) ${ }^{10}$

\section{The Celestial Hierarchy of Angels The Nine Choirs}

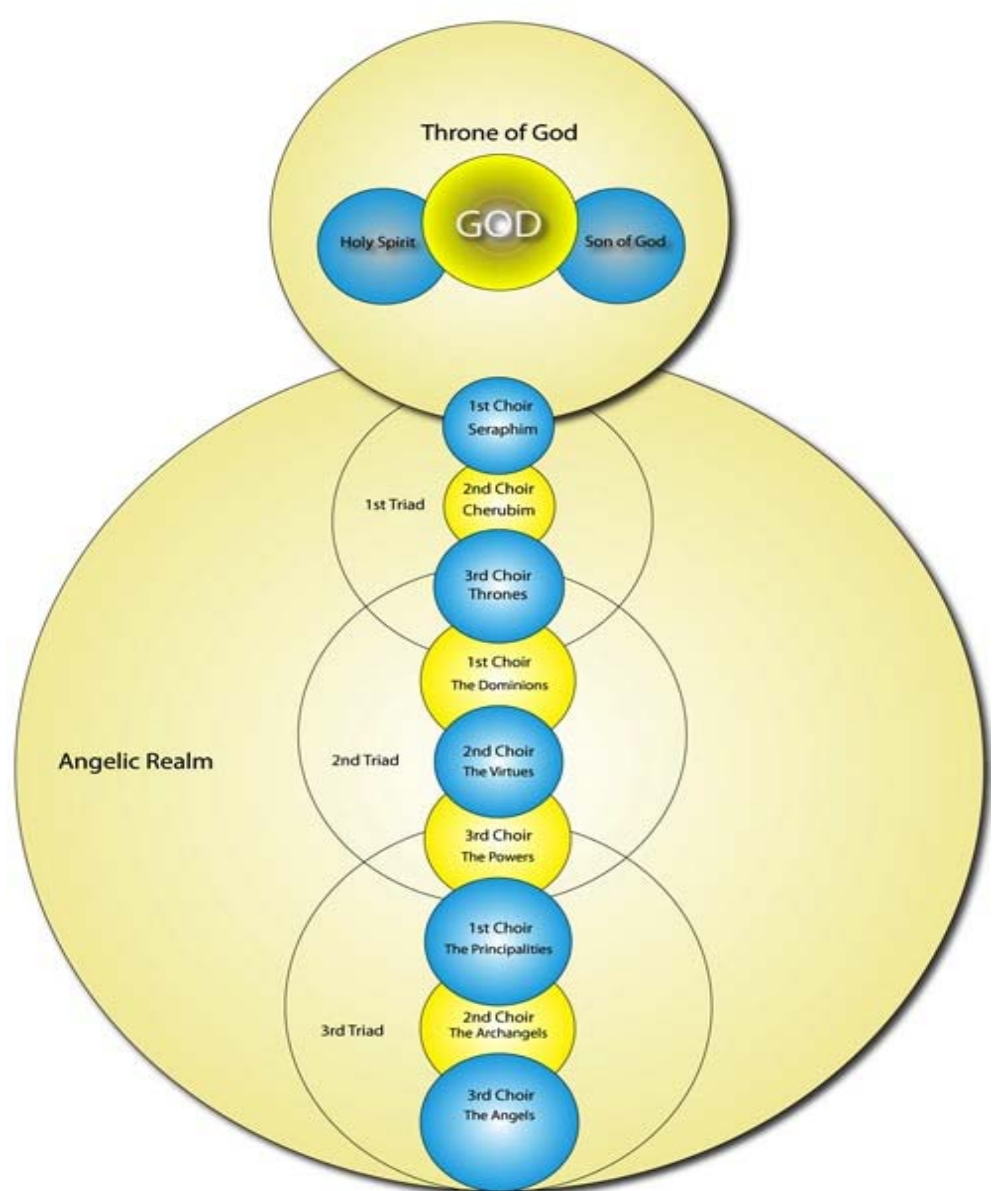

Figure 2. Pseudo-Dionysius the Aeropagite, Celestial Hierarchy, in De coelesti hierarchia (On the Celestial Hierarchy) by Thomas Aquinas' Summa Theologiae. Photo credit: Public domain. http://www.universalonehealing.com/discover-angels/angel-hierarchy-2.

\footnotetext{
9 See G. Heil and A. M. Ritter, eds., Pseudo-Dionysius Areopagita. De Coelesti Hierarchia, De Ecclesiastica Hierarchia, De Mystica Theologia, Epistulae (Berlin: De Gruyter, 1991); and Paul Rorem, “The Uplifting Spirituality of Pseudo-Dionysius,” in Bernard McGinn et al., Christian Spirituality: Origins of the Twelfth Century (New York: Crossroad, 1988), 132-151.

${ }^{10}$ See Saint Thomas Aquinas, Summa Theologiae, vol. 9, ed. and trans. Kenelm Foster (London: Blackfriars and New York: McGraw Hill, 1968), 1a.50-64, on angels; C. A. Patrides, Premises and Motifs in Renaissance Thought and Literature (Princeton: Princeton University Press, 1982), Chapter 1, explaining the order of angels; and Colm Luibheid, ed., Pseudo Dionysius: The Complete Works (New York: Paulist Press, 1987), for further study on the classification of angels.
} 
The placement of Michael The Archangel in the celestial sphere and hierarchy fluctuates between being the seventh highest Seraphim, which means "burning one" (Isaiah 6:1-7), and an Archangel, which means "chief angel” (Thessalonians 4:16). For Aquinas, another influence for classifying the celestial world was the writings of Plotinus (204-70), a Greek Neoplatonic philosopher who noted in the Enneads, in particular in Book IV, his ontological classification from the One (Divine Nous), to the Intellect (Nous or World-Soul) to the Soul (Human Soul or Psyche). ${ }^{11}$ Plotinus' emanations of the one were through celestial light into the metaphysical realm, manifested through the perception of beauty or the Good, and into the natural realm, revealed through forms, properties about objects, or natural substances (Enneads 5.1.6). These emanations (divine light) flowed from one realm into the other in a trajectory of descending stages.

In the Summa Theologiae (1a, 113.3), Aquinas composed an angelic utopia of nine angelic orders or circles. The eighth circle is entrusted to the archangels. They are celestial messengers between God and human beings; they freely ascend and descend between the divine and natural realms. Michael belonged to this order. As a celestial messenger of God, Michael had the divine ability to descend from heaven to earth to assist humans and to ascend back to heaven conveying to God human needs. Thus, for Aquinas, Michael was an angel associated to the court of the Bodiless Powers of Heaven. He was a Prince of the Heaven, a guardian of the Church, since he was the last and lowest in the celestial choir of angels. Aquinas' literary message is embodied in the medieval philosophical poem of Dante Alighieri (1256-1320), The Divine Comedy of 1308-1320. In his drawings of Dante's masterpiece, the Renaissance painter Sandro Botticelli (1445-1510) immortalized the poema sacro, in particular, in the illustration of Paradise, Canto 28, The Angelic Order, where Botticelli visualized Dante's interpretation of Aquinas' vision of the angelic utopia (Figure. 3).

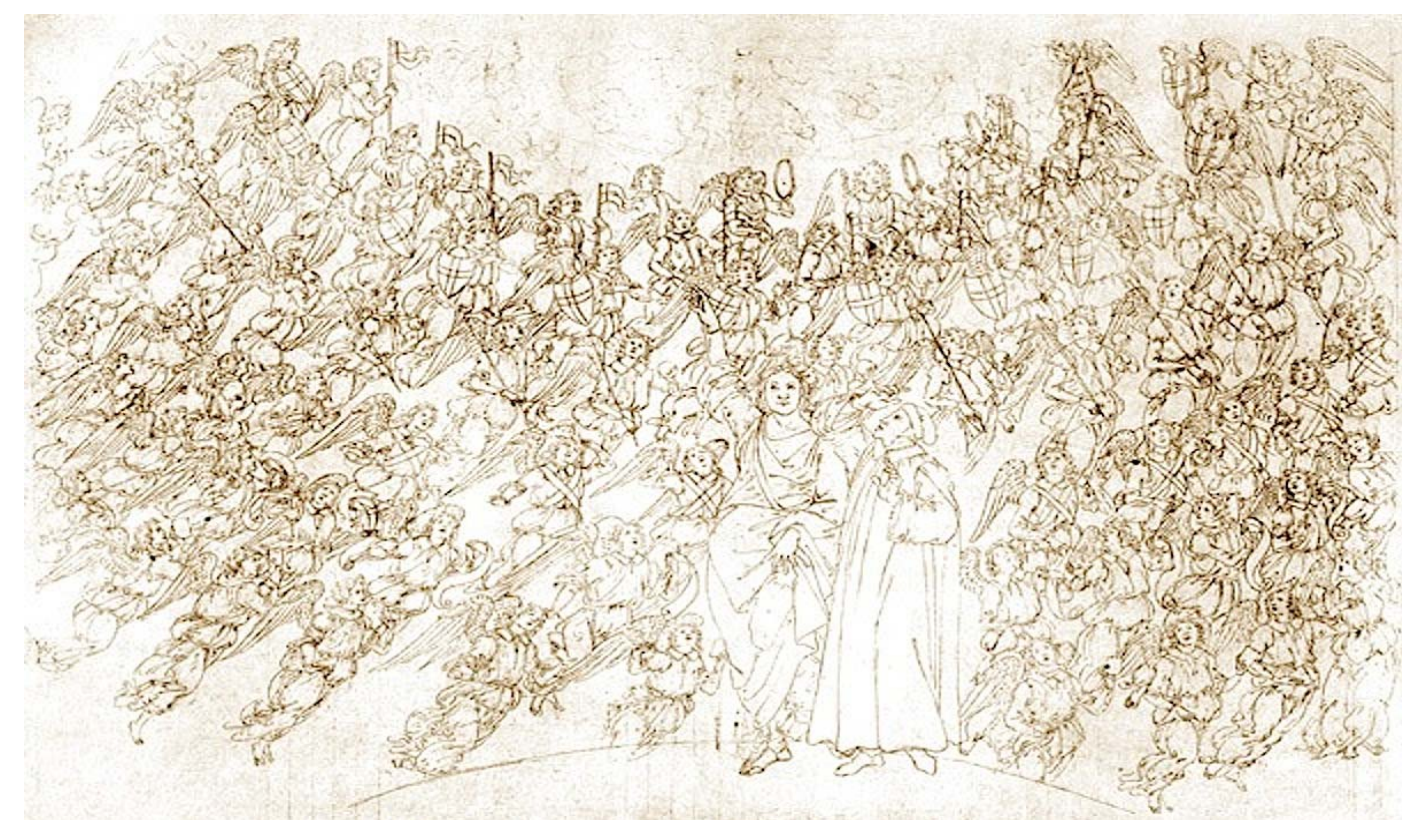

Figure 3. Sandro Botticelli, Dante's Choir of Angels, 1490-95, drawing. from Dante's Divine Comedy, Paradise, Canto 28. Photo credit: Public domain http://www.worldofdante.org/media/images/purg/full/NC257_B7_L55_1921 Paradiso28.jpg.

\footnotetext{
11 See Philip Merlan, “Plotinus Enneads 2.2,” Transactions and Proceedings of the American Philological Association 74 (1943), 179-191, in particular, 186-187; and A. H. Armstrong, Plotinus. Enneads, 9 vols. (Cambridge, MA: Harvard University Press, Loeb Classical Library, 1966-1988), vol. 7, for an edited and comparative translation of Greek-English.
} 
Although Michael was not canonized, he obtained the title of saint because he was an archangel according to the writings of Pseudo Dionysius' angelology, which placed Michael at the top of a celestial hierarchical ladder. Furthermore, during the Middle Ages, the Church Father Bonaventura (Giovanni di Fidanza, 1221-1274) continued to elevate Michael as Seraphim and, in particular, as the Prince of the Seraphim, while Aquinas (Summa Theologiae Ia.113.3) continued to honor Michael as the Prince of the Angels. ${ }^{12}$

Moreover, Michael is associated with sainthood in the Christian litanies of saints. Michael, as an Archangel, is viewed as a saint because of his role as a divine militant for the faith. Unlike most saints, Michael was not a martyr who died on any particular day and then was canonized. It is unclear why his feast days are September 29 in the Roman Catholic calendar and November 21 in the Greek Orthodox calendar. ${ }^{13}$

\section{Section II: The Imagery of Michael The Archangel}

In the visual arts, the imagery of Michael is fused with pagan and Judeo-Christian imagery. For example, Michael is associated with Athena or Minerva, the Goddess of War and Peace from ancient mythological imagery, since both are warriors. Minerva is a defender of secular peace, while Michael is a spiritual defender of virtue (see, e.g., Painter of Palermo's Athena Nike With a Spear and Greave of 470 BCE, an Attic Red-Figure Lekythos, from Gela in Sicily) Athena's attributes of the helmet, cuirass, lance or sword, and snakes are also rendered in Vasari's depictions of Michael (as seen in the drawings of Giorgio Vasari's Saint Michael of 1542, at the Staatliche Graphische Sammlung [n. 2272] in Munich, ${ }^{14}$ and Giorgio Vasari's Saint Michael of 1560-1566, in the Devonshire Collection at Chatsworth House in Derbyshire, UK, for Pope Pius V Chapel, Vatican). ${ }^{15}$

Another pagan connection with Michael's fiery actions and intellectual pursuits is with Hermes or Mercury, Messenger of the Gods. ${ }^{16}$ Both Mercury and Michael are messengers for deities. Both have a fiery nature and reside in a celestial sphere, as illustrated in Sandro Botticelli's Dante and Beatrice in the Sphere of Mercury of 1490-1495, a drawing from Dante's Divine Comedy, Paradise, Canto 6 (Figure. 4), where Mercury's global celestial realm is illustrated with burning flames. Both Mercury and Michael have the ability to fly and ascend or descend in natural and metaphysical realms. Both have wings in their shoulders and boots,

\footnotetext{
12 See Frederic Holweck, “Saint Michael the Archangel,” in The Catholic Encyclopedia 16 vols. (New York: Robert Appleton Company, 1911, reissued 2014), vol. 10; and J. Aertsen, Medieval Philosophy and the Transcendentals: The Case of Thomas Aquinas (Leiden: Brill, 1996).

13 See Cross, ed. The Oxford Dictionary of the Christian Church, 913.

14 See Paola Barocchi, Vasari Pittore (Milan: Club del Libro, 1964), 127, and Julian Kliemann, “Giorgio Vasari: San Michele,” in Laura Corti, ed. Giorgio Vasari (Florence: Edam, 1981), Entry 38, 97. Vasari’s pen and ink drawing of Saint Michael was a gift to the Veronese architect Michele Sanmicheli, in gratitude for securing the commission to paint ceilings in Corner-Spinelli's home in Venice. See also, Giorgio Vasari, Le vite de'più eccellenti pittori, scultori e architettori, eds., Rosanna Bettarini and Paola Barocchi, 6 vols. (Florence: S.P.E.S., 1987), V, 361-79, on the vita of Sanmichele, and 375, on Vasari's description for the imagery. Giorgio Vasari once made for him [Sanmichele] in Venice, with the greatest diligence at his command, a large drawing in which the proud Lucifer and his followers, vanquished by the Angel Michael, could be seen raining destructively coming down from Heaven into the horrible depths of Hell; and at that time Michele did not do anything but thank Giorgio for it when he took leave of him. But no many days after, returning to Arezzo, Giorgio found that Sanmichele had sent long before to his mother, who lived in Arezzo, a quantity of presents beautiful and honorable enough to be the gifts of a very rich nobleman, with a letter in which he did her great honor for love of her son.

${ }^{15}$ See Liana De Girolami Cheney, “Giorgio Vasari’s Saint Thomas of Aquinas and the Heretics in the Chapel of Pius V: A New Discovery, in Vasari in Context, ed. Yael Even, ERIC Special Edition (Summer 2013), 113-120; the chapel was originally named Saint Michael.

${ }_{16}$ Ibid., 198-199; and Vincenzo Cartari, Imagini delli Dei degli’Antichi (Genoa: Nuova Stile Regina Editrice, 1987, repr. of 1647 Venice edition), 165.
} 
wear a helmet, and carry a staff or a sphere. Michael's magical or divine fire is appropriated in the iconography of Mercury, while Michael's radiance and beauty are reflected in the divine nature of Mercury and Minerva.

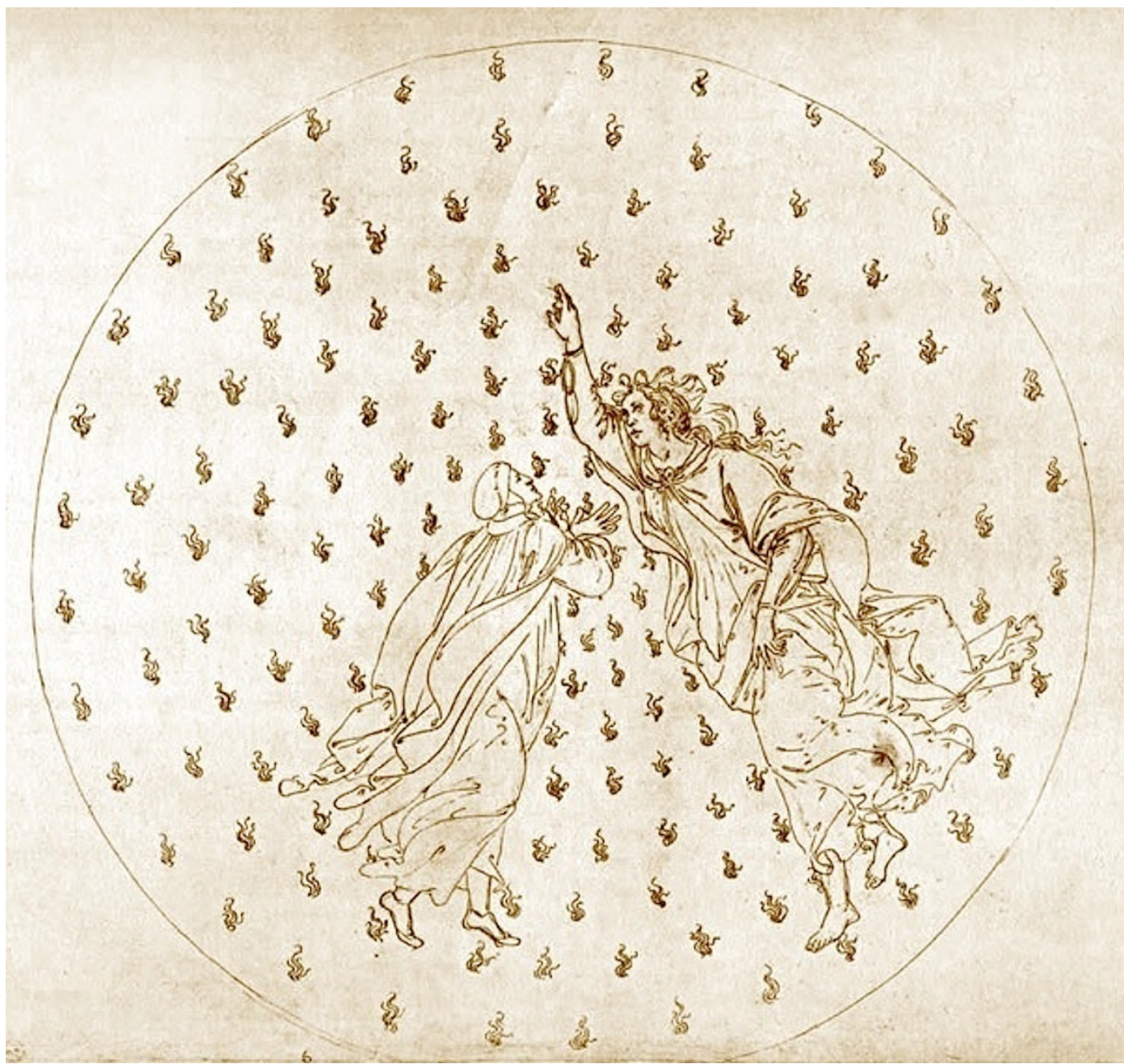

Figure 4. Sandro Botticelli, Dante with Beatrice in The Sphere of Mercury, 1490-95 Dante’s Divine Comedy, Paradise, Canto 6. Manuscript Hamilton 201, Kupferstichkabinett, Berlin. Photo credit: Public domain. http://www.worldofdante.org/media/images/purg/full/NC257_B7_L55_1921Paradiso06.jpg.

In Christian art, Michael imparts several spiritual and secular roles; hence the various attributes in depicting his imagery, including the wings on shoulder and boots, which are associated with flight and with victory as an angel. Sometimes Michael is depicted wearing a helmet, which is an allusion to his role as an angelic warrior. The sword or lance that he carries also alludes to his Christian knighthood or soldier role. The inclusion of animals such as the dragon or a serpent references his combat with the fallen angels or vices. These reptiles are viewed negatively, as devils, in Christian iconography, while in antiquity they were considered a positive force of changeable nature. ${ }^{17}$ For example, when Michael battled the evil forces of darkness represented as monstrous creature with wings such as a serpent or a dragon, he is associated with Saint George, a crusader knight and warrior saint who fought the dragon to defend the captured princes of Saint Margaret (e.g., Giorgio Vasari and assistants' Saint George Slaying the Dragon of 1551, back of the central panel from

${ }^{17}$ See J. E. Cirlot, A Dictionary of Symbols (New York: Philosophical Library, 1962), 83 on the dragon, and 272 on the serpent. 
his family altarpiece in the Badia delle Sante Flora e Lucillaat Arezzo, Figure. 5). The banner with a white and red cross is also Michael's symbol of triumph in his actions (e.g., Fra Filippo Lippi’s Saint Michael of 1456, at the Cleveland Museum of Art in Ohio). The scale refers to Michael's measurement instrument for balancing and judging human souls after their death and on Judgment Day (e.g., Carlo Crivelli's Saint Michael of 1476, at the National Gallery of Art in London). And his carrying an orb is an allusion to his celestial or terrestrial dominions and travels as well as to his divine and human connections (e.g., Saint Michael The Archangel, a Byzantine right leaf ivory of $500 \mathrm{CE}$, at the British Museum in London, with the inscription: "Accept things as they are, even if you learn their causes” [1 Corinthians 2:14]; and Francesco Botticini's The Three Archangels and Tobias of 1467, at the Galleria degli Uffizi in Florence).

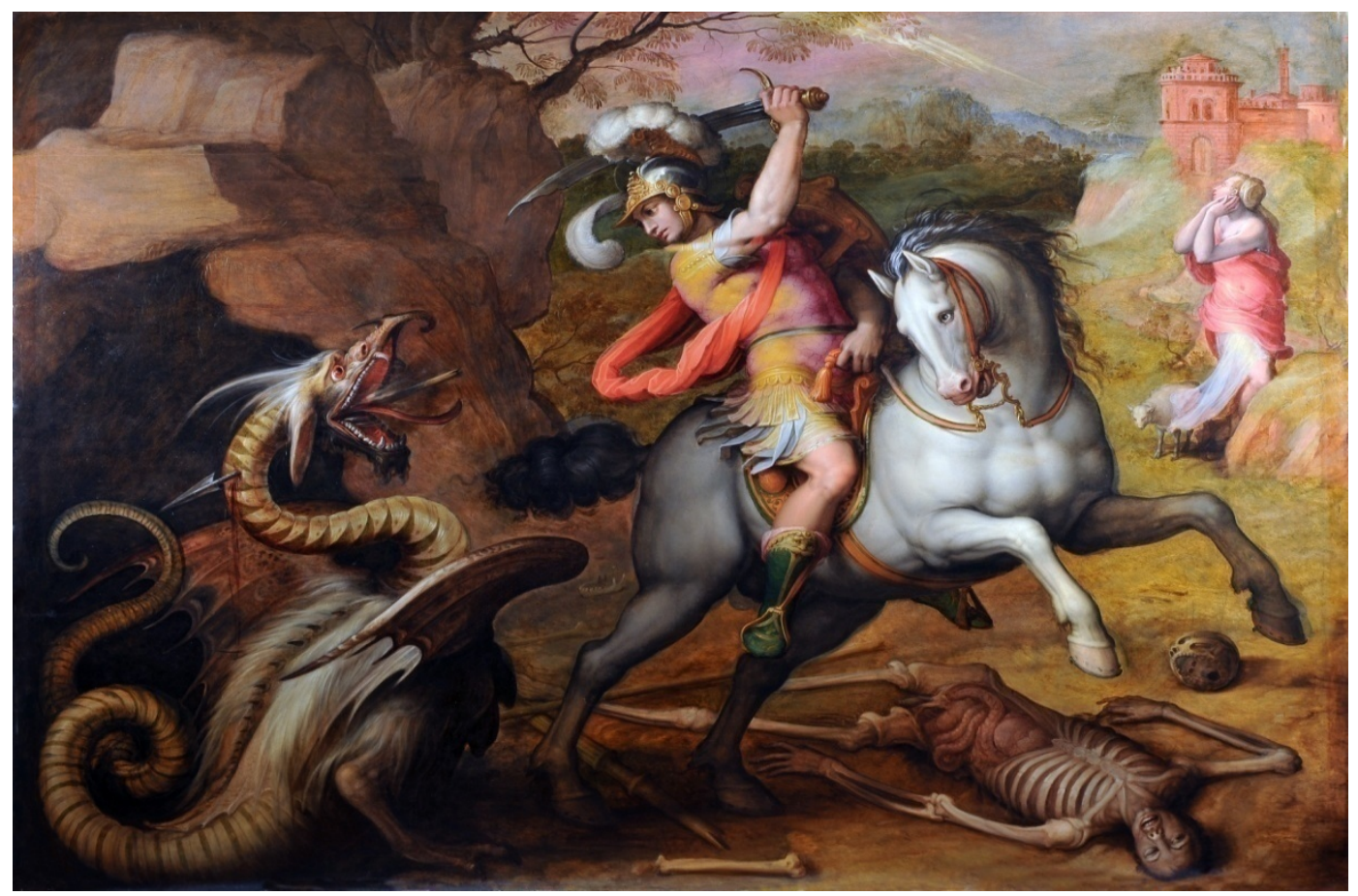

Figure 5. Giorgio Vasari and assistants' Saint George Slaying the Dragon, 1551 Back of the central panel from Vasari’s family altarpiece. Badia delle Sante Flora e Lucilla, Arezzo. Photo credit: author, courtesy of Badia delle Sante Flora e Lucilla, Arezzo.

In his article on "Saint Michael and Attis", Cyril Mango elaborated on the origin of the symbolism of Michael's orb. He objected to the interpretation of two texts. One is found in Sinai (Gr. 482:1117), which stated that the orb or globe is an allusion to "the angels' rapidity of movement; the sphere is such an object that [in barely] touching it [an angel] is able to travel in any direction in less than an instant." 18 The other text mentioned by Mango is a commentary of Symeon of Thessalonica. Here Mango claimed that the author, Symeon, unable to identify the object as an orb, referred to it "as a cloudlike circular object", symbolizing the "sanctification of the Holy Spirit and God's knowledge". ${ }^{19}$ For Mango, the orb has a deeper signification, since it represents a "seal of God", meaning "the presence of the celestial symbols of the sun, moon and the starts" in the creation of the universe. ${ }^{20}$ Present scholarship on the symbolism of the orb considers it to be an object of

\footnotetext{
18 See Mango, “St. Michael and Attis,” 39-40, n. 2.

19 See Mango, "St. Michael and Attis," 39-40, n. 2.

20 See Mango, "St. Michael and Attis", 43-44.
} 
two world powers, "geographically the totality of the universe and juridically the totality of absolute power". ${ }^{21}$ Thus these mentioned attributes are associated with Michael's divine roles as messenger of God, defender of the faith, liberator of evil, and protector and judge of human souls.

\section{Section III: Michael The Archangel and Neoplatonism}

In antiquity, the cause of celestial motion, the movements of the invisible or immaterial realm, is in part explained in Plato's concept of the World-Soul, that is, a circular cosmic motion forms a daily motion of the heaven. ${ }^{22}$ In the Middle Ages, Thomas Aquinas merged Aristotle's positions on the movement of the spheres with Plato's teachings on the World-Soul that related: The "soul shares the motion of its sphere and causes the sphere to move through its love and desire for the unmoved separate intelligence." ${ }^{23}$ Aquinas metaphorically interpreted this motion of Plato's heavenly fire as a Christian love and embodied Michael's nature with a mercurial heavenly fire, since he resided in the realm of the Seraphim. His fire is of two metaphysical natures: divine illumination and spiritual love.

Moreover, Michael's natural and supernatural roles attested to his empowered divinity, which are manifested in his physical actions as a warrior and defender of evil and his metaphysical components of light and love. These aspects reveal Neoplatonic notions in two ways: 1) Michael's nature, action, and conduct reveal symbolic aspects associated with transformation, divine illumination, and charitable love; and 2) his divine ability to descend and ascend from heaven to earth and back again, and his natural (temporal) and spiritual (eternal) life's journey, parallel the journey of the individual soul in its search for the divine.

Another of Michael's aspects is his radiant light and beauty: As a Prince of Light, his spiritual glow illuminates darkness in judgment, while his magical, flaming, natural, and divine fire provides inspiration and healing powers to humankind. In the biblical story of Moses and the burning bush, for example, the magical fire was associated with God's divine presence to heal the Israelites and to grant them an ethical law, The Ten Commandments, God's gift of charity to his people (e.g., Raphael's Moses and the Burning Bush of 1510, in the Logge Vaticane, in Rome). Michael's mercurial nature may be paralleled to the flames in Moses' burning bush and to the natural motions of a seraph, "one who burns with love”. Michael's fiery energy and agility can also be compared to one of Plato's metaphysical realms, the celestial region, which is composed mostly of fire (Plato, Timaeus 40a 2-4) and creates fire's mobility (Plato, Timaeus 55d-56a). ${ }^{24}$ Absorbing Plato's notion of fire from the Timaeus, the Neoplatonic philosopher Plotinus (204-270) also alluded to the circular mobility of fire (Enneads 2.2) ${ }^{25}$ In the Renaissance, the Neoplatonic notions on fire are further encapsulated in the Libro delle Meraviglie of Giovanni Tritemio (1462-1516). This erudite Benedictine theologian referred to the act of divine creation as the "fuoco della creazione" (fire of the creation) or "fuoco divino" (divine fire). ${ }^{26}$

21 See Jean Chevalier and Alain Gheerbrandt, Dictionary of Symbols (London: Blackwell, 1994), 724.

22 See Francis M. Cornford, trans. and annotator, Plato's Cosmology: The Timaeus of Plato (Indianapolis: Bobbs Merrill, Co., 1957), 57-93.

${ }^{23}$ See Harry A. Wolfson, "The Problem of the Souls of the Spheres from the Byzantine Commentaries on Aristotle through the Arabs and St. Thomas to Kepler,” Dumbarton Oaks Papers16 (1962), 65-93.

${ }^{24}$ See Cornford, Plato's Cosmology: The Timaeus of Plato, 118.

25 See Merlan, "Plotinus Enneads 2.2,” 179-191 and 186-187.

${ }^{26}$ See Giovanni Pontano, Lettera sul Fuoco Filosofico (Letter on the Philsophical Fire), ed. Mario Mazzoni (Milan: La Vita Felice, 2011), 31. Ancient Roman religion claims that Numa Pompilio established the cult of the fire. He encouraged the offering of fire burning to the gods in circular formats, representing the circular universe; thus, in this manner, the natural fire became an allusion of sacred fire. See also Giovanni Tritemio, Il Libro delle Meraviglie (The Book of Wonders) (Rome: La Lebre, 2012, repr. of the 1508 edition). 
Thus the fire in Moses' burning bush, for example, alludes to two meanings. In the natural realm, the fire reveals God's diffusion of divine love on earth through the deliverance of Michael's transformation from a heavenly Seraphim into a natural fire. And in the metaphysical realm, the spiritual trajectory of Michael from heaven to earth and back to heaven symbolizes the human soul's journey to ascend from earth to heaven reaching for God. Michael's descent to earth in the form of a flaming bush is in order to deliver God's message on the creation of his covenant, The Ten Commandments, which provided for Moses God's laws and guidance for his people on their life's journey. Michael's return to heaven to partake of his celestial sphere of Archangels and Seraphim implies two meanings on the deliverance of God's messages: 1) it refers to educating human souls on God's grace; and 2) it demonstrates how to reach paradise with God's grace in order to contemplate God for eternity.

In The Book of the Ascent and Descent of the Intellect, written circa in 1305 and published in 1512 in Valencia, Raymond Llull (1232-1315), a Catalan philosopher and mystic, depicted a celestial ladder of ascent and descent of the intellect, visualizing the hierarchy of creation (e.g., Raymond Llull's Celestial Ladder, from De Nova Logica, 1305 [Valencia 1512 reprint], at the Bibliothèque Nationale in Paris). ${ }^{27}$ This ladder contains nine steps, which represent the levels of physical and metaphysical formations of the reachable world, descending from superior to inferior or vice versa. The levels include ascension from an inorganic to an organic world, from the animal to the human, and from the human to the divine, e.g., from bottom to top, lapis (stone), flamma (fire/elements), pianta (plant/vegetation), brutum (beast/animal), homo (human beings), caelum (sky), angelus (angel), and Deus (God). The angelus level connects with God as well as with the individual. Michael, for example, because of his angelic status, resides in the angelus level. Being close to God's perimeter, he ascends and descends the ladder, transmitting and delivering God's messages on from heaven to earth, while dispersing good and abhorring evil, emanating God's light and love.

Llull was well versed in Neoplatonism, in particular, on Plotinus' Enneads (Book IV, 8), which deals with the intelligible world and the ascending and descending of the soul. ${ }^{28}$ In turn, the Renaissance Neoplatonic philosopher Marsilio Ficino (1433-1499) was familiar with Llull's notions. In De Amore, Chapter 1, "Love is in Everything," Ficino discussed God's benevolent governance over the angels and, together with the angels, God's governance over the human souls. ${ }^{29}$ Thus Ficino, alluding to the emanation of God's grace or love, christianizes Plotinus' emanations of the One, that is, he parallels Neoplatonic light with Christian grace.

In Llull's nine steps, there are basic attributes apprehended by the human intellect in order to comprehend God's creation. These divine dignities-Goodness, Greatness, Eternity (Duration), Power, Wisdom, Will, Virtue, Truth, and Glory_are in the Creator (God) and also inherited by human beings, who are imitations of God. In Llull's woodcut, these divine dignities are depicted in a circle, confirming their equal significance, unlike the physical and metaphysical formations, which are depicted in an ascending nine steps or levels denoting levels of transformations in the life.

The translation by the Camaldolese General Ambrogio Travesari (1386-1439) of Pseudo-Dionysius the Areopagite’s Mystical Theology, Divine Names, Ecclesiastical Hierarchies and Celestial Hierarchies (MS Laur.

\footnotetext{
${ }^{27}$ See M.D. Johnston, “Ramon Llull’s Language of Contemplation and Action,”Modern Language Studies, Oxford Journal vol. xxvii, no. 2 (1991), 100-112.

${ }_{28}$ See Jennifer Yhap, Plotinus On the Soul: A Study in the Metaphysics of Knowledge (London: Associated Press, 2003), 44, on the ascent and descent of the soul; and Riccardo Chiaradonna, Plotino (Plotinus). (Rome: Carrocci, 2012), 81-115.

${ }_{29}$ See Marsilio Ficino, De Amore (Sopra Lo Amore ovvero Convito di Platone), ed. Giuseppe Rensi (Milan: SRL, 2003 ), 47 and 85.
} 
Gaddiano LXXXV, Florence) further inspired Ficino's Neoplatonic conciliation between Christianity and paganism. Dennis F. Lackner has noted that Traversari employed a traditional dialogue format and discussed the relationship between Platonic philosophy and Christian Scriptures, in particular, explaining the doctrine of the human soul by the prisci theology (ancient theologians). The conclusion to the debate is to "renounce the Platonic doctrine of the soul's pre-existence, and yet affirm the soul's immortality as well as the resurrection of body through the grace and power of God, thus achieving a synthesis of Platonic and Christian thought”. ${ }^{30}$

Fortuitously, during 1480-1490, Traversari was the Camaldolese General of the church of S. Maria degli Angeli in Florence, where Ficino presented his oratio on Plato: "in the sede angelorum [seat of angels, named after the monastery], we contemplated divine truth," ${ }^{31}$ and "delivered numerous Platonic commentaries with the encouragement of angels”. 32

Ficino explained the signification of the Platonic celestial ladder as a spiritual training for monks in terms of the inorganic and organic world, the human mind and the soul, the angelic soul and the intelligible. He examined the Platonic theory of the Intelligence as a rational process. But when discussing the power of Divine Love, Ficino made a leap of faith, considering it a supernatural phenomenon. ${ }^{33}$ Ficino said, "From natural things, one ascends to divine things, and this is why no one can ever understand the sublime mysteries of Plato, unless he has already been initiated into the discussion of Aristotle.”34 Furthermore, Divine Love is imparted in the world through the level of the Angelic Mind, the realm in which Michael resides. The Angelic Mind transmits to the Human Mind in the form of a "scintilla di lume" (sparkling light), the splendor of God's love. ${ }^{35}$ Desirous of this Divine Love, the Human Mind, guided by the Angelic Mind, achieves felicity and harmony. ${ }^{36}$

Michael The Archangel, being of celestial intelligence (that is, Ficino's Angelic Mind) and partaking of the celestial sphere, moves from the celestial sphere to the terrestrial sphere, delivering God's messages to the souls of the faithful. This transitory path of descending to earth and ascending to heaven, or intellectually making visible the invisible realm, is metaphorically visualized in Renaissance paintings of Jacob's Dream of the Angelic Ladder, where angels journey from heaven to earth and back by descending and climbing a ladder, e.g., Giorgio Vasari's The Dream of Jacob of 1558, at The Walters Art Museum in Baltimore, MD. ${ }^{37}$ Vasari has absorbed Ficino's Neoplatonic message on the ladder's symbolism.

In 1560, Vasari further visualized the splendor of Michael The Archangel and his arduous combat against celestial aggressors, the demons, in the vault of Pope Pius V Chapel at the Vatican. In the Holy Scriptures, Saint Michael is mentioned as the protector of the Church and the Guardian Angel of the pope, an iconography related to the pope's mission of eradicating the heretics from the Christian (now Catholic) Church. ${ }^{38}$ In his

\footnotetext{
30 See Dennis F. Lackner, "The Camaldolese Academy: Ambrogio Traversari, Marsilio Ficino and the Christian Platonic Tradition,” in Michael J. B. Allen and Valery Rees with Martin Davies, eds., Marsilio Ficino: His Theology, His Philosophy, His Legacy (Leiden: Brill, 2001), 21.

31 See Lackner, “The Camaldolese Academy,” 31, citing Ficino’s Opera omnia, 886.

32 See Lackner, “The Camaldolese Academy,” 32, citing Ficino’s Opera omnia, 951.

33 See Lackner, "The Camaldolese Academy," 38.

34 See Lackner, “The Camaldolese Academy,” 40, citing Ficino, Opera omnia, 953.

${ }^{35}$ See Ficino, De Amore, 86, and Marsilio Ficino, De Sole (The Book of the Sun), Chapter XII (1494), trans. and ed. Geoffrey Cornelius, et al. <http://www.users.globalnet.co.uk/ alfar2/ficino.htm>.

${ }^{36}$ See Ficino, De Amore, 84.

37 See Liana De Girolami Cheney, “Giorgio Vasari’s Dream of Jacob: A Neoplatonic Manifestation of Heaven,” in Vasari in Context, ed. Yael Even, ERIC (Summer 2013), 113-120.

${ }^{38}$ See Alban Butler, The Lives of the Fathers, Martyrs and Other Principals Saints, 12 vols. (New York: Dublin James Duffy, 1866, and New York: Bartleby.Com 2010), vol. 1, 117; and Cross, The Oxford Dictionary of the Christian Church, 1095-06.
} 
ricordo 360, Vasari outlines the design for three chapels for the new Pope Pius V. ${ }^{39}$ The chapel of Saint Michael is the first chapel to be decorated. On December 2, 1570, Vasari notes that he is in Rome commencing the decoration of the first chapel, Cappella di San Michele. ${ }^{40}$ He further elaborates on the description of the imagery. He depicts stories of Saint Michael, alluding to the eponymous name, Michael, selected by the pope when he entered the Dominican order. In the vault ("che [nel] la volta viera il cielo aperto dagli Angeli” [that in the vault there was a sky covered with Angels]), ${ }^{41}$ the chapel is decorated with Michael The Archangel leading an army of seven good angels against seven sinners, alluding to Michael holding fast against the revolt of Lucifer's bad angels and seven deadly sins (Figures. $1 \mathrm{~A}$ and B). ${ }^{42}$

With Mannerist brilliant colors and inventive compression of space, Vasari unveiled the drama of the combat between good and evil and the protection of divine love. He designed an elliptical vortex where, in a swirling motion, seven angels (including Michael The Archangel) combat seven demons, which represent the seven deadly sins. In an ascending order, the vortex is composed of three levels of ellipses, the largest one of burning buildings, flaming fires, and thick smoky clouds. These eruptions and destructions were caused by the demons that now are being castigated by Michael's angels. The second level is depicted with copious clouds and an atmospheric zone decorated with pinks, violets, and light gray colors. From this celestial level, Michael and his angels descend to cast out the nude and deformed winged demons. The messengers of God are dressed in their finest military attire. Vasari depicted the angels with 16th-century military garments, plumed helmets, colorful military cuirasses, and boots. They victoriously battle with lances and swords. The pink, yellow, mint-green, chartreuse, orange, and lilac colors of the angels' attire contrast with the green and flesh tones of the monstrous bodies of the demons. The last elliptical level is depicted as a golden, radiant crown composed of heavenly angels and cherubs who together illuminate and guard the city of God. In the center of their circle, a white brilliant light reveals the presence and beauty of the Holy Spirit, the purity and essence of God's grace and love.

\section{Conclusion}

In sum, in an explosive coloration and spiral movement of space, Vasari demonstrated his artistic creativity, technical talent, and thematic originality as a virtuoso Mannerist painter. He also captured Saint

\footnotetext{
39 See Giorgio Vasari, Libro delle Ricordanze, ed. Alessandro del Vita (Arezzo: Tipografia Zelli, 1938), carta 29 verso, 102-103; Karl Frey, Der literarische Nachlass Giorgio Vasaris II (Munich: George Müller, 1930), 471-473 475-476; 485, 527, 547 and 882; Archivio Vasariano, cod II (45) n. 43, c. 75 (Notizie riguardanti i lavori eseguiti sulla volta della Cappella di S. Pietro Martire fral il 4 e il 17 Febbraio 1571); Barocchi, Vasari Pittore, 68-70; Kliemann, "Giorgio Vasari: San Michele,” in Corti, ed. Giorgio Vasari, 96-97; and Laura Corti, Vasari (Florence: Cantini, 1989), 138-140.

40 See Frey, Der literarische Nachlass Giorgio Vasaris, II, 547. In a letter to Prince Francis I of Florence, Vasari informs him that he is beginning to paint the first chapel for Pope Pius V. In the vault of this first chapel, he depicts "a shower of the dark angels, a new invention, difficult to capture but of great variety" ("Ho dato principio alla prima cappella ... nella volta di questa prima cappella ci fo la pioggia degli angioli neri, che sara cosa nuova, difficile et molto varia”). Vasari continues to elaborate on the depiction. In the vault, "these seven angels combat with the seven mortal sins ("questi sette angeli, che combattevono coi sette peccati mortali"). Although in 1542, under the influence of Renaissance painters, he composed an inventive drawing on the theme of San Michael fighting Lucifer, Vasari revealed the magnitude of his talent and creativity in the imagery of Saint Michael and the Devils on the ceiling for the papal chapel (Figure. 1).

${ }^{41}$ See Vasari, Libro delle Ricordanze, ed. Alessandro del Vita, carta 29 verso, 102-103.

42 In the Devonshire Collection at Chatsworth Castle in England, there are two drawings associated with the ceiling decoration: Saint Michael Vanquishing Satan with a Sword of 1566; and Saint Michael Vanquishing Satan with a Lance of 1566. Vasari's drawings reflect his observations of Albrecht Dürer's Apocalypse of 1498. See Michael Jaffé, The Devonshire Collection of Italian Drawings (London: Phaidon Press, 1994), 142. See also the earlier drawing on Saint Michael that Vasari designed for Michele Sanmichele at the Staatliche Graphische Sammlung in Munich.
} 
Michael's virtuosity with Neoplatonic connotations, that is, The Archangel's ability to descend and ascend from heaven to earth, transmitting his spiritual power of illumination and love; his ability to combat the negative forces of demons in the self and in the world; his cunning transformation and elevation of the natural human soul into a heavenly loving soul (Angelic-Soul) for the sole purpose of contemplating God. Thus Vasari's Michael The Archangel purified the earth's darkness after the demons' burning fire into a radiant heaven of pure golden light.

\section{References}

Aertsen, J. (1996). Medieval philosophy and the transcendentals: The case of Thomas Aquinas. Leiden: Brill.

Barocchi, P. (1964). Vasari Pittore. Milan: Club del Libro.

Bettarini, R., \& Barocchi, P. (Eds.). (1987). Le vite de'più eccellenti pittori, scultori e architettori (Vols. 1-6). The lives of the most excellent painters, sculptors and architects). Florence: S.P.E.S..

Butler, A. (1866). The lives of the Fathers, Martyrs and other Principals Saints (Vols. 1-12). New York: Dublin James Duffy.

Butler, A. (2010). The lives of the Fathers, Martyrs and other Principals Saints (Vols. 1-12). New York: Bartleby.Com.

Cheney, L. De G., (2013). Giorgio Vasari’s dream of Jacob: A Neoplatonic manifestation of Heaven. In L. De G. Cheney and Y. Even (Ed.), Vasari in context. ERIC (Summer 2013) (pp. 7-25).

Cheney, L. De G., (2013). Giorgio Vasari’s San Thomas of Aquinas and the Heretics in the Chapel of Pius V: A New Discovery. In L. De G. Cheney and Y. Even (Ed.), Vasari in context. ERIC special edition (2013) (pp. 113-120).

Chevalier, J., \& Gheerbrandt, A. (1994). Dictionary of symbols. London: Blackwell.

Chiaradonna, R. (2012). Plotino (Plotinus). Rome: Carrocci.

Cornelius, G. et al. Marsilio Ficino's De Sole (The Book of the Sun), 1494 . Retrieved from http://www.users.globalnet.co.uk/ alfar2/ficino.htm

Cornford, F. M. (Trans. and annoted). (1957). Plato's cosmology: The Timaeus of Plato. Indianapolis: Bobbs Merrill, Co..

Corti, L. (1989). Vasari. Florence: Cantini.

Corti, L. (Ed.). (1981). Giorgio Vasari. Florence: Edam.

Cross, F. L. (Ed.). (1984). The Oxford dictionary of the Christian church. Oxford/New York: Oxford University Press.

Ficino, M. De A. (Sopra Lo Amore ovvero Convito di Platone) (Ed.). (2003). Giuseppe Rensi. Milan: SRL.

Foster, K. (Ed. and Trans.). (1968). Saint Thomas Aquinas' Summa Theologiae (Vol. 9). London: Blackfriars and New York: McGraw Hill.

Frey, K. (1923). Der literarische Nachlass Giorgio Vasaris (Vols. 1-2). Munich: George Müller.

Frey, K. (1930). Der literarische Nachlass Giorgio Vasaris (Vols. 1-2). Munich: George Müller.

Ginzberg, L. (1909). The legend of the Jews (Vols. 1-2). Philadelphia: The Jewish Publication Society of America, 1909, reprinted by Charleston, SC: Nabu Press, 2010.

Heil, G., Ritter, A. M. (Eds.). (1991). Pseudo-Dionysius Areopagita. De Coelesti Hierarchia, De Ecclesiastica Hierarchia, De Mystica Theologia, Epistulae (Pseudo-Dionysius Areopagita, Celestial Hierarchy, Hierarchy of the Church, Letters on Mystical Theology). Berlin: De Gruyter.

Holweck, F. (1911). Saint Michael the Archangel in the Catholic Encyclopedia (Vols. 1-16). New York: Robert Appleton Company, 1911 and reissued 2014, Vol. 10.

Hurll, E. M. (Ed.). (1895). Sacred and legendary art by Anna Jameson. Boston: Houghton Mifflin and Company.

Jaffé, M. (1994). The Devonshire collection of Italian drawings. London: Phaidon Press.

Johnston, M. D. (1991). Ramon Llull's language of contemplation and action. Modern Language Studies, Oxford Journal, 27(2), 100-112.

Kliemann, J. (1981). Giorgio Vasari, L. Corti, (Ed.). Florence: Edam, Entry 38, 96-97.

Lackner, D. F. (2001). The Camaldolese academy: Ambrogio Traversari, Marsilio Ficino and The Christian Platonic tradition. In Michael J. B. Allen, V. Rees, M. Davies (Eds.). Marsilio Ficino: His theology, his philosophy, his legacy. Leiden: Brill.

Luibheid, C. (Ed.). (1987). Pseudo Dionysius: The complete works. New York: Paulist Press.

Mango, C. (1986). St. Michael and Attis. Deltion tes Christianikes Archaiologikes Hetaireas (Deltion of the Christian Archeological Society), 12(4), 39-62. 
Merlan, P. (1943). Plotinus Enneads 2.2. Transactions and Proceedings of the American Philological Association, 74, 179-191 and 186-187.

Norwich, J. (Ed.). (1999). The book of Revelations on Divine Love. Baltimore, MD: Penguin Books.

Patrides, C. A. (1982). Premises and motifs in renaissance thought and literature. Princeton: Princeton University Press.

Pontano, G. (2011). Lettera sul Fuoco Filosofico (Letter on the Philosophical Fire). M. Mazzoni. (Ed.). Milan: La Vita Felice.

Rorem, P. (1988). The uplifting spirituality of pseudo-dionysius. In B. McGinn et al. (Eds.), Christian spirituality: Origins of the twelve century (pp. 132-151). New York: Crossroad.

Starr, M. (2007). Saint Michael: The Archangel. Louisville, CO: Sounds True.

Vanhaelen, M. (2013). Marsilio Ficino and the irrational. In M. Israëls and L. A. Waldman (Eds.), Renaissance studies in honor of Joseph Connors (Vols.1-2) (Vol. 2, pp. 440-443). Cambridge, MA: Harvard University Press.

Vasari, G. (1938). Libro delle Ricordanze. A. del Vita, (Ed.). Arezzo: Tipografia Zelli.

Walker, A. (Ed.). (1873). Revelations of Moses, The Apocryphal Gospels. Edinburg: np, 1873. Retrieved from http://www.newadvent.org/cathen/10275b.htm

Webster, R. (2010). Michael. Woodbury, MN: Llewellyn Worldwide.

Wolfson, H. A. (1962). The problem of the souls of the spheres from the Byzantine commentaries on Aristotle through the Arabs and St. Thomas to Kepler. Dumbarton Oaks Papers, 16, 65-93.

Yhap, J. (2003). Plotinus on the soul: A study in the metaphysics of knowledge. London: Associated Press. 